\title{
Models of historical biogeography and continental biochronology
}

\author{
María Ángeles ÁLVAREZ-SIERRA ${ }^{1,2 *}$, Israel GARCÍA-PAREDES ${ }^{1,2}$, Verónica HERNÁNDEZ- \\ BALLARÍN ${ }^{3}$, LATS W. VAN DEN HOEK OSTENDE 4 , Kees HORDIJK ${ }^{5}$, Paloma LÓPEZ- \\ GUERRERO ${ }^{1,2}$, Albert J. VAN DER MEULEN ${ }^{5}$, Adriana OLIVER ${ }^{3}$ \& Pablo PELÁEZ- \\ CAMPOMANES ${ }^{3}$
}

\footnotetext{
${ }^{1}$ Departamento de Paleontología, Facultad de Ciencias Geológicas, Universidad Complutense de Madrid, José Antonio Novais 2, 28040 Madrid, Spain; masierra@geo.ucm.es; palomalopez@geo.ucm.es

${ }^{2}$ Departamento de Geología Sedimentaria y Cambio Medioambiental, Instituto de Geociencias IGEO (CSIC, UCM), José Antonio Novais 2, 28040 Madrid, Spain; isgarpa@geo.ucm.es

${ }^{3}$ Departamento de Paleobiología, Museo Nacional de Ciencias Naturales MNCN, CSIC, José Gutiérrez Abascal 2, 28006 Madrid, Spain; verohernandez@mncn.csic.es; adriana@mncn.csic.es; pablopelaez@mncn.csic.es

${ }^{4}$ Naturalis Biodiversity Center, Darwinweg 2, 2333 CR Leiden, The Netherlands; Lars.vandenHoekOstende@naturalis.nl

${ }^{5}$ Institute of Earth Sciences, Utrecht University, Budapestlaan 4, 3584 CD Utrecht, The Netherlands; K.Hordijk@uu.nl

* Corresponding author
}

Álvarez-Sierra, M.A., García-Paredes, I., Hernández-Ballarín, V., Van den Hoek Ostende, L.W., Hordijk, K., López-Guerrero, P., Van der Meulen, A.J., Oliver, A. \& Peláez-Campomanes, P. 2013. Models of historical biogeography and continental biochronology. [Modelos de biogeografía histórica y biocronología continental]. Spanish Journal of Palaeontology, 28 (2), 129-138.

\section{ABSTRACT}

One of the most important contributions of Nieves López Martínez in Palaeobiogeography is the study of the 'centre of origin of species' concept and the proposal of the 'Asymmetric Time Model' as an alternative to the 'Symmetric Time Model', a key concept in dispersalist Historical Biogeography. As a consequence of these ideas, she discussed the methodology to establish biostratigraphic scales, pointing out that the higher number of 'First Appearance Datum' (FADs) over that of 'Last Appearance Datum' (LADs) in the fossil record supports the Asymmetrical Time Model. In this study we analyse the middle Miocene micromammal appearance and extinction events (FADs and LADs) based on well-calibrated local biostratigraphic scales from different European basins, in order to determine which of the proposed biogeographical models better fits the Miocene

\section{RESUMEN}

Entre las aportaciones de Nieves López Martínez a la Paleobiogeografía, se puede destacar el estudio del concepto de 'centro de origen de un taxón' y la propuesta del 'Modelo Temporal Asimétrico' como alternativa al 'Modelo Temporal Simétrico’, concepto básico de la Biogeografía Histórica dispersalista. A partir de estas ideas analizó la metodología de construcción de las escalas bioestratigráficas, señalando que el mayor número de eventos de primera aparición (FAD) en el registro fósil frente a los de última aparición (LAD) confirmaría el Modelo Temporal Asimétrico. En este trabajo se analizan los eventos de aparición y extinción (FADs y LADs) reconocidos en escalas bioestratigráficas locales bien calibradas de diferentes cuencas europeas, con el fin de comprobar cuál de los modelos biogeográficos se ajusta mejor al registro europeo de micromamíferos miocenos. Los 
European micromammal record. The results support that the Asymmetric Time Model of palaeobiogeography is only applicable in rare cases. The analysed fossil record only shows one event of occurrence and one of extinction that can be considered synchronous at continental level. Finally, the implications of the biogeographic models in the proposition of biochronologic continental scales are also discussed, pointing out that palaeobiogeographic frameworks need robust biochronologies based on extensive local biostratigraphic data with independent temporal correlation.

Keywords: Micromammals, Historical Biogeography Symmetric/Asymmetric Time Model, dispersals, middle Miocene correlations, diachrony. resultados confirman que el Modelo Temporal Asimétrico de paleobiogeografía es aplicable a pocos casos. En el registro fósil analizado sólo hay un evento de aparición y otro de extinción que pueden considerarse sincrónicos a nivel continental. Finalmente, se discuten las implicaciones de los modelos biogeográficos en las propuestas de escalas biocronológicas continentales, destacando que los trabajos paleobiogeográficos necesitan tener como marco de referencia sólidas escalas biocronológicas, basadas en numerosos datos de bioestratigrafías locales correlacionadas temporalmente de manera independiente.

Palabras clave: Micromamíferos, Modelo Temporal Simétrico/Asimétrico de Biogeografía Histórica, dispersión, correlaciones del Mioceno medio, diacronía.

\section{INTRODUCTION}

Throughout her prolific professional career, Nieves López Martínez was known for her vast knowledge in many fields of Palaeontology, Geology and Biology. Specifically, Palaeobiogeography focused her interest as a teacher and as a researcher. During almost thirty years she gave undergraduate and graduate lectures on Biogeography and Palaeobiogeography at the Autónoma and Complutense universities of Madrid (UAM and UCM, respectively). This experience let her to address some palaeobiogeographic questions in several publications (e.g., López Martínez, 2001, 2003, 2009). One of her most interesting contributions in this area is the study of the 'centre of origin of species' concept, one of the most important and controversial issues (considered even as inapplicable and non-scientific by e.g., Croizat et al., 1974) in Historical Biogeography. She argued that methodologies based on the recent distributions, like finding the area with maximum diversity or that with the most primitive representatives, were disputable. Using the fossil record and finding the oldest and, ideally, most primitive representative of a lineage seems a better approach. However, in practice this has not led to unambiguously identifying the ancestral area for any lineage (LópezMartínez, 2009).

The somewhat disappointing results in using palaeontological finds were explained by López-Martínez (2003, 2009) by the very nature of the fossil record. New taxa always seem to appear simultaneously over a larger area, and this rapid expansion is that makes many foraminifers, brachiopods, molluscs and mammals such excellent biostratigraphic/biochronologic markers. Based on these observations, López Martínez (2003, 2009) analysed the so-called 'Symmetric Time Model' (the symmetric model for theoretical life-span of a species suggested by Jenkins, 1994), a key concept in dispersalist biogeography. Rather than having a gradually expanding distribution area after origination and a gradually decreasing area before extinction, as explained in the symmetric model, she proposed the alternative (and partially opposite) 'Asymmetric Time Model', which implies a rapid dispersal at the beginning, but maintaining the gradual extinction (Fig. 1).

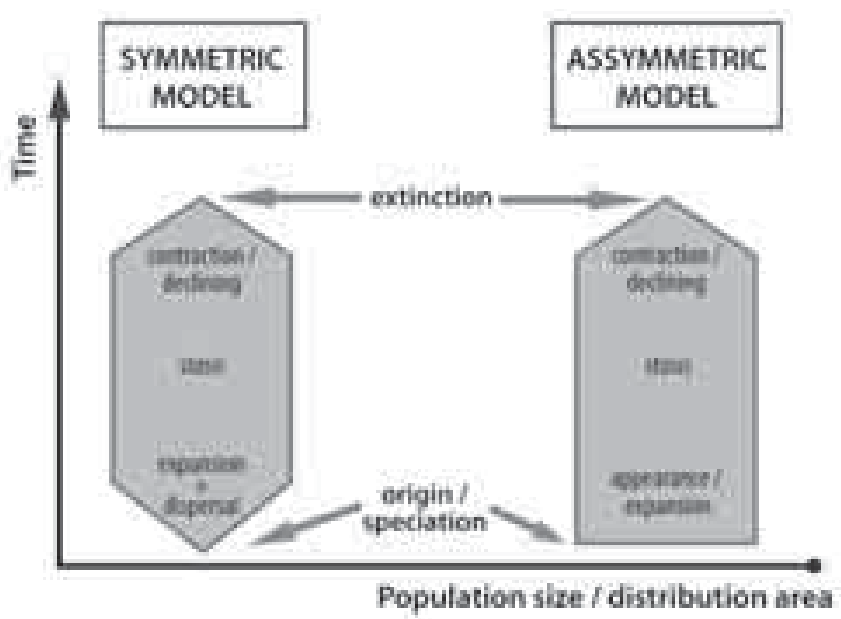

Figure 1. Spatiotemporal distribution diagrams of the existence of a species according to the considered models. Symmetric Time Model (Jenkins, 1994): a new species is originated as a small population in the centre of origin, it gradually disperses and expands its geographic area, undergoes a period of stasis (oversimplified in the model) and a gradual contraction followed by its extinction when the last small population disappears. Asymmetric Time Model (López Martínez, 2003): a new species is originated and rapidly expands its entire geographic range, undergoes a period of stasis (oversimplified in the model) and a gradual contraction followed by its extinction when the last small population disappears. Modified after López Martínez (2003). 
As a consequence of the proposed model, López-Martínez addressed the methodology to establish biostratigraphical scales, pointing out that the higher number of First Appearance Datum (FAD) over that of Last Appearance Datum (LAD) in biostratigraphical schemes, such as that of De Graciansky et al. (1998) for marine microfossils, supports her 'asymmetrical' model (López-Martínez, 2009; fig. 4).

In this paper, we examine the appearance and extinction events of micromammal (FADs and LADs) in continental basins for the construction of chronologic scales. As in the marine realm, FADs and LADs sequences have been proposed but, unlike the latter, they have rarely been based on well-calibrated local biostratigraphic scales covering all involved areas. In general, a biogeographic 'asymmetric model' (rapid appearance/expansion of a taxon) has been assumed, despite the partial absence of solid criteria to select the bio-events. The main aim is to determine which of the proposed models better fits the Miocene European micromammal record, using the correlations of bio-events recently published by Van der Meulen et al. (2011, 2012). We surmise that dispersal events in the continental realm may encounter more obstacles than those in the marine one because of the higher heterogeneity of habitats and the role played by the geographical barriers, and therefore consider the micromammal fossil record an important test case for the general applicability of the Symmetric/Asymmetric Time Models. Based on the obtained result, we also discuss the implication of assuming each of these models in the proposition of biochronologic continental scales.

\section{CASE STUDY: THE EUROPEAN MIDDLE MIOCENE RODENTS}

Europe stands out as one of the best sampled areas for fossil of micromammals, which over the last fifty years has led to an impressive fossil record. For the middle Miocene, this record is particularly well sampled in Central Spain, southern Germany, and Switzerland. Moreover, palaeomagnetic data are available for fossiliferous sections in the three areas allowing long distance correlations. The increase on the knowledge of these three micromammal records allows further refinement in the study of bio-events (FADs and LADs). They also represent two different bioprovinces and provide a unique opportunity to compare different faunal histories through time.

Van der Meulen et al. (2011, 2012) correlated the sections from the Aragonian type area to the record of the Upper Freshwater Molasse (OSM) in the North Alpine Foreland Basin (Fig. 2). Two biozonations have been proposed for the latter area, one by Kälin \& Kempf (2009) for the Swiss part of the basin, the other by Abdul Aziz et al. (2010) for the Bavarian sections. Unfortunately, the two Central European zonations differ in their chronological interpretations, particularly for the older zones. Therefore,
Van der Meulen et al. (2011) suggested an alternative interpretation of the age of the Bavarian zonation, based on the data from Abdul Aziz et al. (2010).

Founded on these correlations, Van der Meulen et al. (2012) checked the syn/diachronicity of thirteen rodent bio-events. Notably, many of these events are commonly used as important markers in the MN-zonation (Mein, 1975a, b, 1999, 2000). Their analyses showed that most of these events are diachronic. Though they appear in nearly the same sequence in Spain as in Central Europe, first occurrences of many taxa were found to be sometimes substantially later in the Iberian Peninsula. In fact, only two of these events were considered synchronic: the first occurrence of the hamster Democricetodon and the last occurrence of the eomyid Ligerimys florancei Stehlin \& Schaub, 1951. The record shows that various other hamster genera (Megacricetodon, Eumyarion, Cricetodon, Cricetulodon) did not disperse over all of Europe at the same time, nor did a number of species which are generally considered to be useful biostratigraphic markers such as Megacricetodon gersii Aguilar, 1980, M. minor (Lartet, 1851), and Ligerimys florancei. Given the importance allotted to these taxa in the MN-zonation, Van der Meulen et al. (2011) cautioned that this widely used system displays, at least in part, strong diachrony. This problem has been previously pointed out, in a general overview of the MN system, by others authors (Daams \& Freudenthal, 1981; Fahlbusch, 1991; Van Dam et al., 2001; Van Dam, 2003; Gómez Cano et al., 2011).

\section{DISCUSSION ON BIOGEOGRAPHIC TIME MODELS}

Based on the obtained results, the dispersal pattern of middle Miocene rodents does not seem to follow the Asymmetric Time Model as a general pattern, contrary to the conclusions of López-Martínez (2003, 2009), since they do not appear throughout Europe simultaneously. Democricetodon is the only exception, but then again, this genus was present in Anatolia even before the middle Miocene (Theocharopoulos, 2000), so it too had a more limited geographical range to start with. Democricetodon would act as invasive taxon expanding rapidly, probably related to the demise of geographic/ecological barriers. The appearance of the 'Gomphotherium landbridge' at the end of the MN3 could contribute to the entry of Democricetodon, and other mammals, into Europe (Koufos et al., 2005); Van der Made (1999) pointed out that this mammals event may be related to the regression of the TB2.2 cycle of Haq et al. (1987) or to the changes in the climate caused by this regression. Other taxa that can be considered invasive (Megacricetodon, Cricetodon, and the lagomorph Prolagus) do not fit in the biogeographic asymmetric model. 


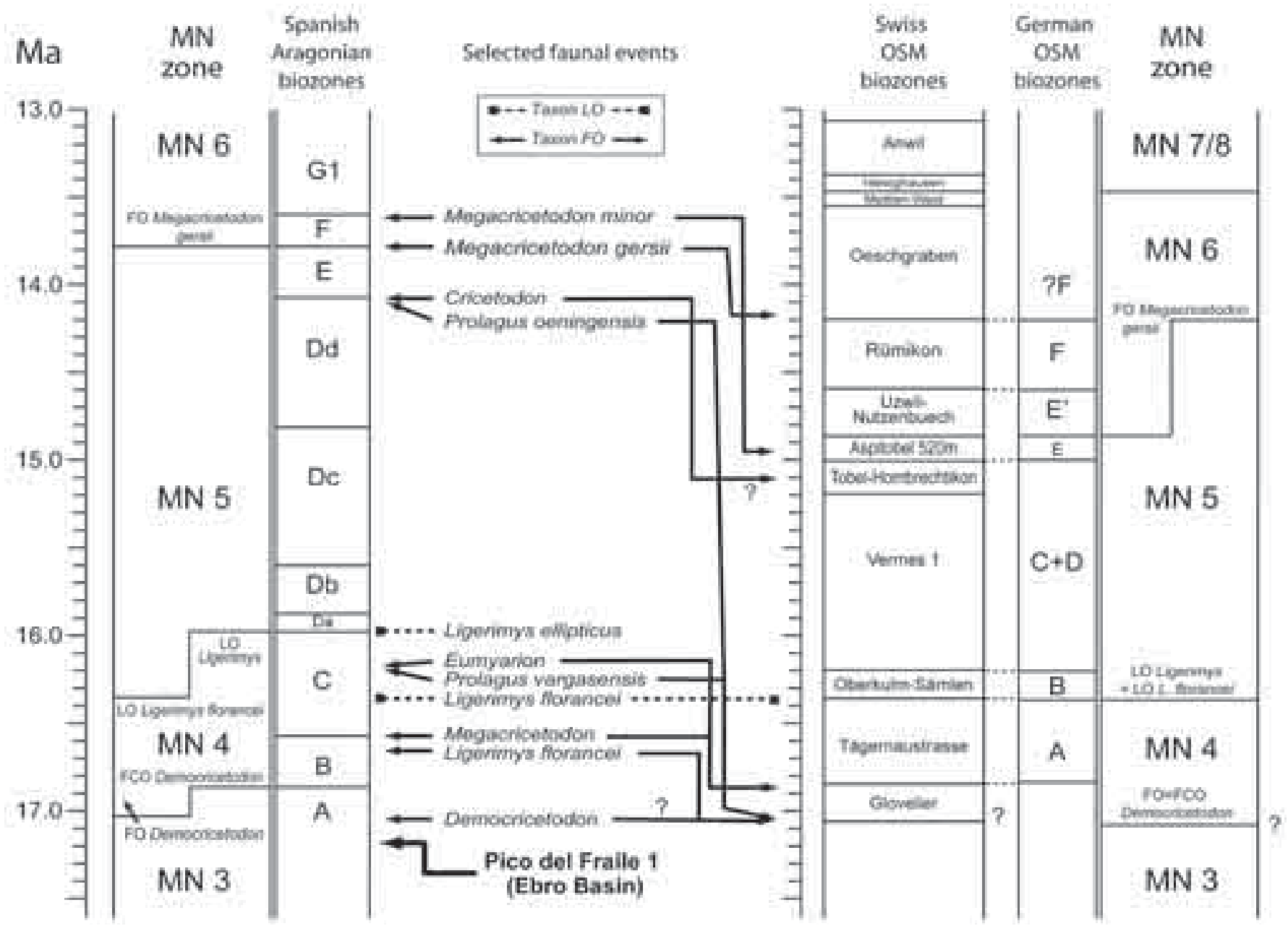

Figure 2. Selected micromammal events and correlations of the Spanish Aragonian type area, the Swiss Upper Freshwater Molasse (OSM) and the Bavarian Upper Freshwater Molasse (OSM) in Germany. Modified after Van der Meulen et al. (2011, 2012).

Having rejected the generality of the Asymmetric Time Model for our dataset, the question arises if a symmetric model provides a better fit for small mammal data. There are indications that it does. We already noted that Democricetodon started with a limited range in Anatolia before spreading into Europe, and it is not the only cricetodontine that followed this pattern. Megacricetodon and Cricetodon were also already present in that region in the Early Miocene (De Bruijn et al., 2013). If we consider the record of the entire tribe Cricetodontini in Europe and Asia Minor (including the genera Cricetodon, Hispanomys, Byzantinia, Deperetomys, and Ruscinomys), it seems to follow the Symmetrical Time Model of Jenkins (1994) fairly well (Figs 3,4$)$. The appearance of the taxon occurs in a small area (region of Anatolia) during the Early Miocene. In the Middle Miocene there is a gradual expansion into Central Europe and France, followed by a period of stasis in which the taxon is distributed over most Europe and Asia Minor. Since the Late Middle Miocene, the distribution area of the representatives of the tribe starts to show fragmentation and contraction that precede the extinction at the end of the Pliocene. The scarcity of fossil sites with remains of Cricetodontini during the latest stadium is not related to the lack of localities at that age (Fig. 3). A quite similar pattern was found by Van den Hoek Ostende (2001) for the gymnure Galerix. That insectivore was first found in Anatolia only, became spread across Europe during the later part of the Early Miocene, and retracted its range to the Iberian Peninsula during the Middle Miocene, with only one patchy occurrence in Germany at the very end of that period (Prieto et al., 2011).

By their very nature, models are always oversimplifications of the actual processes with are supposed to explain. The research by Jenkins $(1992,1994)$ was focussed on the end stage of biogeohistories. The gradual expansion after origination was rather theoretically based. We pose that a truly gradual expansion is, in fact, unlikely. In their study of the Iberian small mammal record, Van Dam et al. (2006) 




Figure 3. Palaeogeographic maps for the Early Miocene (20.5-19 Ma) to the Mid late Pliocene (3.5-2.59 Ma) of Europe and Asia Minor (modified after Popov et al., 2004) showing the spatiotemporal distribution of the tribe Cricetodontini. The spots point the location of certain fossil sites showing "real absence" in the contraction period. Data actualized and modified after Rummel, 1999; Hilgen et al, 2012; López-Guerrero et al., 2013; and NOW database (Fortelius, coord., 2013). 


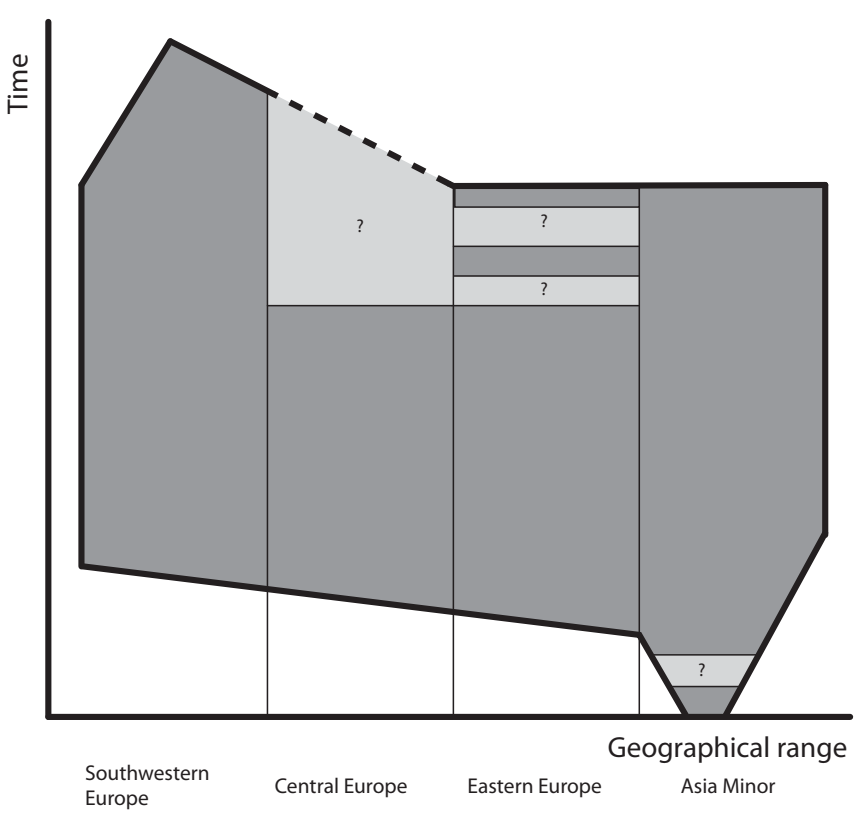

Figure 4. Schematic example of the temporal and geographical distribution of the genera of Cricetodontini in Europe and Asia Minor, which seems to follow the Asymmetrical Time Model. The light grey, the discontinuous line as well as the exclamation marks represent the uncertainties in the ranges for the genera. The temporal and geographical scales are qualitative.

demonstrated that faunal turnovers are punctuated, and can be correlated to astronomical cyclicity. These faunal turnovers were calculated from the sum of origination and extinction events, as shown by first and last occurrences in the fossil record. Having periods of climatic instability that promote faunal turnover could lead to a stepwise dispersal. If a taxon during such a period would find favourable enough conditions to settle in Central Europe, but not yet in Spain, it could have to wait till the next period of faunal turnover to disperse further. Such a stepwise pattern is also the result of a changing palaeogeography with areas separated by geographical and/or ecological barriers. These barriers, rather than as corridors, have functioned as filters that allow the dispersion of certain taxa, probably based on their environment requirements or due to the presence of competitors in that environment. For instance, in the case of the lagomorph Prolagus, both environment and potential competitors seem to have played a role in invading the Iberian Peninsula (Hordijk, 2010). What seems clear is that the dispersal model for each taxon is unique and involve, at least, one of the three types of dispersal events: jump dispersion - colonization of new areas over long distance in a relatively short period of time - diffusion - movement into adjacent areas from the margins of the range of the taxonand secular migration - very slow dispersal event that commonly involves evolutionary changes in the taxa.

\section{MAMMAL BIOCHRONOLOGY AND BIOGEOGRAPHIC TIME MODELS}

Biochronology and biogeography can be considered interdependently. Both have three fundamental processes that explain their spatial and temporal biotic patterns: dispersal, evolution and extinction. Traditionally, regional or continental biochronological scales have been proposed either, based on the combination of local biostratigraphic information (extensively used in marine biochronology), or on interpretations of the evolutionary stage of the fossil associations (mostly used in continental biochronology) (Fahlbush, 1991; Van Dam, 2003; Woodburne, 2004). The general geographical and temporal discontinuity of the continental stratigraphic record and the high geographic differentiation of mammalian faunas, consequence of a higher environmental heterogeneity, has promoted the use of biochronologic scales based mainly on palaeobiological events (Mein, 1975; Agustí et al., 2001; Van Dam, 2003; Van der Meulen et al., 2011). This procedure, though in principle theoretically sound, has in fact demonstrated to have many limitations, mainly caused by the lack of robust phylogenetic hypotheses for most of the groups, needed to build up a reliable palaeobiological chronology. Although, the general sequence of recognizable palaeobiological events could be similar along broad areas, there is no reason to consider them as isochronous as discussed by Walsh (1989), and shown by Van der Meulen et al. (2011). This a priori conception used on the biochronologic scales has also influenced palaeobiogeography and thus the biogeographic time model that explains it, becoming a circular reasoning. Therefore Biochronology and Palaeobiogeography must be based on data with external time correlation to avoid this circular reasoning. This is the motivation why more and more authors have claimed that Mammal biochronology needs a better, and more explicit, foundation based on biostratigraphy (e.g., Woodburne, 2006; Van der Meulen et al., 2011, 2012).

Finally, we would like to comment on the suggestion made by López-Martínez (2003, 2009) about the support for the Asymmetric Time Model based on the higher frequency of FADs against LADs on biochronological scales. In our opinion the higher number of FAD is not the consequence of a general rapid dispersal of organisms. We believe that biostratigraphers simply have a preference for using the presence of a taxon (positive criterion), rather than its absence (i.e., the commonly known 'absence of evidence is not evidence of absence' due to undersampling, biased sampling, taphonomy, etc.). The International Stratigraphic Guide (Salvador, 1994) recommends the use of the "Highest occurrence zone" type of Interval Zone for subsurface stratigraphic work while recommends the use of "Lowest occurrence zone" on surface works. Therefore the proportion of FADs and LADs must be biased towards FADs if the biochronology is mainly based on surface stratigraphy. 


\section{CONCLUSIONS}

The detailed analysis of palaeobiological events studied on the middle Miocene micromammal associations from well-calibrated local biostratigraphic scales from different European basins supports the rarity of cases where the Asymmetric Time Model of Biogeography applies. Theoretically, these events fit the Symmetric Time Model better.

The analyzed fossil record shows only one occurrence event (Democricetodon) and one extinction event (Ligerimys florancei) that can be considered fast (synchronous) at a continental scale. Therefore, the MN scale, based on appearances and extinctions of species, suffers from problems of asynchrony of the biochrons between the different areas.

Nevertheless, the dispersal patterns observed cannot be considered as gradual. They show a stepwise pattern, probably primarily related to the changing environment in response to punctuated climatic changes.

Biogeography and Biochronology are interdependent and therefore their interpretations are dependent on their respective working hypothesis. In this way we have shown that depending on the dispersal model the authors have in mind, faunal correlations and chronology will be strongly different and therefore the palaeobiogeographic framework.

To avoid circular reasoning and a priori misconceptions, a robust biochronology based on extensive local biostratigraphic data with independent temporal correlation, is needed.

\section{ACKNOWLEDGEMENTS}

Nieves, we want to express our sincere and deep gratitude for your teachings, for your help and advices, and for everything you gladly shared with each of the authors of this work. Thanks to the editors of the series of volumes homage to Nieves López Martínez, who have made possible to discuss and converse about some of "the things we left to tell you". We thank the reviewers Drs I. Casanovas (Institut Català de Paleontologia, ICP) and M. Hernández Fernández (Universidad Complutense de Madrid, UCM), who provided helpful suggestions and updated references that have improved considerably the manuscript. We also wish to thank Sergio Pérez for the artistic reconstruction of Cricetodon that illustrates this work, and all the colleagues, students and friends that helped us during many years in the fieldwork and the processing of the micromammal samples. This work is a contribution to the Spanish MICINN/MINECO projects CGL2008-04200/ BTE, CGL2011-28877, and the Universidad Complutense de Madrid Research Group UCM-910607 "Evolution of Cenozoic Mammals and Continental Palaeoenvironments”. IG-P is supported by a JAE-Doc contract (CSIC program "Junta para la Ampliación de Estudios", co-funded by the European Social Fund) and by the Spanish MICINN/ MINECO project CGL2010-21672. PL-G acknowledges a UCM Predoctoral contract and a "Martin Fellowship" grant at the NBC (The Netherlands). VHB and AO are supported by FPI and FPU predoctoral contracts (MICINN/ MINECO), respectively.

\section{REFERENCES}

Abdul Aziz, H., Böhme, M., Rocholl, A., Prieto, J., Wijbrans, J., Bachtadse, V. \& Ulbig, A. 2010. Integrated stratigraphy and ${ }^{40} \mathrm{Ar} /{ }^{39} \mathrm{Ar}$ chronology of the early to middle Miocene Upper Freshwater Molasse in western Bavaria (Germany). International Journal of Earth Sciences, 99, 1859-1886.

Aguilar, J.P. 1980. Nouvelle interpretation de l'evolution du genre Megacricetodon au cours du Miocene. Paleovertebrata Montpellier, Mémoire Jubilaire René Lavocat, 355-366.

Agustí, J., Cabrera, L., Garcés, M., Krijgsman, W., Oms, O. \& Parés, J.M. 2001. A calibrated mammal scale for the Neogene of Western Europe. State of the art. EarthScience Reviews, 52, 247-260.

Croizat, L., Nelson, G. \& Rosen, D.E. 1974. Centers of origin and related concepts. Systematic Zoology, 23, 265-287.

Daams, R. \& Freudenthal, M. 1981. Aragonian: the Stage concept versus Neogene Mammal Zones. Scripta Geologica, 62, 1-17.

De Bruijn, H., Ünay, E. \& Hordijk, K. 2013. A review of the Neogene succession of the Muridae and Dipodidae from Anatolia with special reference to taxa known from Asia and/or Europe. In: Fossil Mammals of Asia: Neogene Biostratigraphy and Chronology (eds. Wang, X, Fortelius, M. \& Flynn, L.). Columbia University Press, New York, in press.

De Graciansky, P.C., Hardenbol, J., Jacquin, T. \& Vail, P.R. (eds.) 1998. Mesozoic and Cenozoic Sequence Stratigraphy of European Basins. Society for Sedimentary Geology (Society of Economic Paleontologists and Mineralogists), Tulsa, Special Publication 60.

Fahlbusch, V. 1991. The meaning of MN-zonation: considerations for a subdivision of the European continental Tertiary using Mammals. Newsletters on Stratigraphy, 24, 159-173.

Fortelius, M. (coord.) 2013. New and Old Worlds Database of Fossil Mammals (NOW). University of Helsinki. http:// www.helsinki.fi/science/now/.

Gómez Cano, A.R., Hernández Fernández, M. \& ÁlvarezSierra, M.A. 2011. Biogeographic provincialism in rodent faunas from the Iberoccitanian Region (southwestern Europe) generates severe diachrony within the Mammalian Neogene (MN) biochronologic scale during the Late 
Miocene. Palaeogeography, Palaeoclimatology, Palaeoecology, 307, 193-204.

Haq, B. U., Hardenbol, J. \& Vail, P. R. 1987. Chronology of Fluctuating Sea Levels Since the Triassic. Science, 235, 1156-1167.

Hilgen, F.J., Lourens, L.J. \& Van Dam, J.A. 2012. The Neogene Period. In: Geologic Time Scale 2012 (eds. Gradstein, F.M., Ogg, J.G. \& Schmitz, J.G.). Cambridge University Press, Cambridge, pp. 923-978.

Hordijk, K. 2010. Perseverance of pikas in the Miocene. Interplay of climate and competition in the evolution of Spanish Ochotonidae (Lagomorpha, Mammalia). Geologica Ultraiectina, 333, 1-232.

Jenkins, D.G. 1992. Predicting extinctions of some extant planktic foraminifera. Marine Micropaleontology, 19, 239-243.

Jenkins, D.G. 1994. Predicting extinctions. In: Extinción y registro fósil (ed. Molina, E.). Cuadernos Interdisciplinares $\mathrm{N}^{\mathrm{o}} 5$, Seminario Interdisciplinar de la Universidad de Zaragoza, 219-227.

Kälin, D. \& Kempf, O. 2009. High-resolution stratigraphy from the continental record of the Middle Miocene Northern Alpine Foreland Basin of Switzerland. Neues Jahrbuch für Geologie und Paläontologie Abhandlungen, 254, 177-235.

Koufos, G.D., Kostopoulos, D.S. \& Vlachou, T.D. 2005. Neogene/Quaternary mammalian migrations in Eastern Mediterranean. Belgian Journal of Zoology, 135, 181190.

Lartet, E. 1851. Notice sur la colline de Sansan, suivie d'une récapitulation des diverses espèces d'animaux vertébrés fossiles, trouvés soit à Sansan, soint dans d'autres gisements du terrain tertiaire miocène dans le Bassin Sous-Pyrénéen. J.A. Portes, Auch.

López-Guerrero, P., García-Paredes, I. \& Álvarez-Sierra, M.Á. 2013. Revision of Cricetodon soriae (Rodentia, Mammalia), new data from the middle Aragonian (middle Miocene) of the Calatayud-Daroca Basin (Zaragoza, Spain). Journal of Vertebrate Paleontology, 33, 169184.

López-Martínez, N. 2001. Paleobiogeographical history of Prolagus, an European ochotonid (Lagomorpha). Lynx, n.s. 32, 215-231.

López-Martínez, N. 2003. La búsqueda del centro de origen en Biogeografía Histórica. Graellsia, 59, 503-522.

López-Martínez, N. 2009. Time asymmetry in the palaeobiogeographic history of species. Bulletin de la Société géologique de France, 180, 45-55.

Mein, P. 1975a. Résultats du groupe de travail des vertébrés: Biozonation du Néogène Mediterranéen à partir des Mammifères. In: Report on Activity of R.C.M.N.S. Working Groups (1971-1975) (ed. Senes, J.). VIth Congress of the Regional Committee of Mediterranean Neogene Stratigraphy, Bratislava 1975, p. 78-81.

Mein, P. 1975b. Proposition de Biozonation du Neogene Mediterraneen a partir des mammiferes. Trabajos sobre Neógeno/Cuaternario, 4, 112-113.
Mein, P. 1999. European Miocene Mammal Biochronology. In: The Miocene land mammals of Europe (eds. Rössner, G. \& Heissig, K.). Verlang Dr. Friedrich Pfeil, München, p. 25-38.

Mein, P. 2000. La biochronologie des mammifères néogènes d'Europe. L'échelle MN, son application à la succession des faunes du Portugal. Ciências da Terra (UNL), 14, 335-342.

Popov, S.V., Rögl, F., Rozanov, A.Y., Steininger, F.F., Shcherba, I.G. \& Kovac, M. (eds.) 2004. LithologicalPaleogeographic maps of Paratethys. Courier Forschungsinstitut Senckenberg, 250, 1-46.

Prieto, J., van den Hoek Ostende, L.W. \& Böhme, M. 2011. Reappearance of Galerix (Erinaceomorpha, Mammalia) at the Middle to Late Miocene transition in South Germany: biostratigraphic and palaeoecologic implications. Contributions to Zoology, 80, 179-189.

Rummel, M. 1999. Tribe Cricetodontini. In: The Miocene Land Mammals of Europe (eds. Rössner, G.E. \& Heissig, K.). Verlag Dr. Friedrich Pfeil, München, 359-364.

Salvador, A. (ed.) 1994. International Stratigraphic Guide - A guide to stratigraphic classification, terminology, and procedure. The International Union of Geological Sciences, The Geological Society of America, Boulder, Colorado.

Stehlin, H.G. \& Schaub, S. 1951. Die Trigonodontie der simplicidentaten Nager. Schweizerische paläontologische Abhandlungen, 67, 1-385.

Theocharopoulos, K.D. 2000. Late Oligocene-Middle Miocene Democricetodon, Spanocricetodon and Karydomys n. gen. from the Eastern Mediterranean area. Gaia, 8, 1-116.

Van Dam, J., Alcalá, L., Alonso Zarza, A., Calvo, J.P., Garcés, M. \& Krijgsman, W. 2001. The Upper Miocene mammal record from the Teruel-Alfambra region (Spain). The MN system and continental stage/age concepts discussed. Journal of Vertebrate Paleontology, 21, 367-385.

Van Dam, J.A. 2003. European Neogene mammal chronology: past, present and future. Deinsea, 10, 85-95.

Van Dam, J.A., Abdul-Aziz, H., Álvarez Sierra, M.A., Hilgen, F.J., van den Hoek Ostende, L.W., Lourens, L., Mein, P., van der Meulen, A.J. \& Peláez-Campomanes, P. 2006. Long-period astronomical forcing of mammal turnover. Nature, 443, 687-691.

Van den Hoek Ostende, L.W. 2001. Insectivore faunas from the Lower Miocene of Anatolia. Part 8: Stratigraphy, palaeoecology, palaeobiogeography. Scripta Geologica, 122, 101-122.

Van der Made, J. 1999. Intercontinental relationship EuropeAfrica and the Indian Subcontinent. In: The Miocene Land Mammals of Europe (eds. Rössner, G.E. \& Heissig, K.). Verlag Dr. Friedrich Pfeil, München, p. 457-473.

Van der Meulen, A.J., García-Paredes, I., Álvarez-Sierra, M.A., van den Hoek Ostende, L.W., Hordijk, K., Oliver, A., López-Guerrero, P., Hernández-Ballarín, V. \& PeláezCampomanes, P. 2011. Biostratigraphy or biochronology? Lessons from the Early and Middle Miocene small Mammal Events in Europe. Geobios, 44, 309-321. 
Van der Meulen, A.J., García-Paredes, I., Álvarez-Sierra, M.A., van den Hoek Ostende, L.W., Hordijk, K., Oliver, A. \& Peláez-Campomanes, P. 2012. Updated Aragonian biostratigraphy: Small Mammal distribution and its implications for the Miocene European Chronology. Geologica Acta, 10, 159-179.

Walsh, S.L. 1998. Fossil datum and paleobiological event terms, paleontostratigraphy, chronostratigraphy, and the definition of Land Mammal “Age” boundaries. Journal of Vertebrate Paleontology, 18, 150-179.

Woodburne, M.O. 2004. Principles and procedures. In: Late Cretaceous and Cenozoic mammals of North America: Biostratigraphy and geochronology (ed. Woodburne, M.O.). Columbia University Press, New York, p. 1-20.

Woodburne, M.O. 2006. Mammal ages. Stratigraphy, 3, 229-261. 
